\title{
TIME AND PROCESS OF SPERM PENETRATION INTO HAMSTER OVA IN VIVO AND IN VITRO
}

\author{
R. YANAGIMACHI \\ Worcester Foundation for Experimental Biology, Shrewesbury, Massachusetts, U.S.A., \\ and Zoological Institute, Faculty of Science, Hokkaido University, Sapporo, Japan
}

(Received 18th September 1965)

Summary. Female golden hamsters were mated at various times before or after ovulation, and the time of sperm penetration into the ova was examined. When the females were mated several hours prior to ovulation, penetration of spermatozoa into the ova started about $3 \mathrm{hr}$ after the commencement of ovulation or about $1.5 \mathrm{hr}$ after the first ovum passed into the Fallopian tube; virtually all the ova were penetrated in the next $4 \mathrm{hr}$. In the females mated during or several hours after ovulation, sperm penetration occurred between 3 and $6 \mathrm{hr}$ after coitus. The experiments in which spermatozoa were deposited artificially in the uteri of females shortly after ovulation, demonstrated that the spermatozoa recovered from the uterus of other females penetrated ova significantly faster than epididymal spermatozoa. The uterine spermatozoa deposited about the ova in vitro were also able to penetrate the ova more quickly than epididymal spermatozoa. The whole process of sperm penetration through the zona pellucida was observed on one occasion. This particular observation showed that: (1) the acrosome (at least, the outer acrosome membrane) of the fertilizing spermatozoon was absent before the spermatozoon started to penetrate the zona pellucida; (2) the direction of the passage of the spermatozoon was not vertical, but at an angle to the surface of the zona pellucida; (3) the time required for the sperm head to traverse the zona pellucida and the perivitelline space was 3 to $4 \mathrm{~min}$ and 1 to $2 \mathrm{sec}$, respectively; and (4) the head of the spermatozoon lay flat on the vitelline surface and sank into the vitellus without lively movements of the sperm flagellum.

\section{INTRODUCTION}

The time relationship between mating and penetration of spermatozoa into the ova has been studied in several species of laboratory animals. Austin \& Braden (1954) reported that when rats were mated before ovulation, penetration of spermatozoa into the ova did not start immediately after ovulation, but 2 to $4 \mathrm{hr}$ later. A similar delay was observed in the mouse (Braden \& Austin, 1954) and in the golden hamster (Austin, 1956; Strauss, 1956), where it was 3 to $5 \mathrm{hr}$ and $2 \mathrm{hr}$ respectively. Such an interval between ovulation and the commencement of sperm penetration was interpreted as suggesting the 
necessity for physiological maturation of the ova (Austin, 1956; Strauss, 1956) or of the cumulus oophorus surrounding the ova (Braden, 1962). When females are mated before or shortly after ovulation, follicular cells surrounding the ova disperse after the ova have been penetrated by spermatozoa. This is particularly true of the mouse (Lewis \& Wright, 1935), rat (Austin, 1948; Odor \& Blandau, 1951) and rabbit (Moricard \& Bossu, 1949), although the ability of spermatozoa to penetrate the naked ova is well established (Austin, 1951; Chang \& Bedford, 1962).

Evidence has also been presented to show that there is a delay between mating and sperm penetration of the ova, even when the animals are mated several hours after ovulation. This is about $2 \mathrm{hr}$ in the rat (Austin \& Braden, 1954) and about $4 \mathrm{hr}$ in the hamster (Strauss, 1956). Since the first spermatozoon may reach the site of fertilization (ampullary portion of the Fallopian tube) within $1 \mathrm{hr}$ of coitus (Blandau \& Money, 1944; Austin, 1952; Yanagimachi \& Chang, 1963), the interval between mating and the commencement of sperm penetration may be ascribed to the necessity for the spermatozoa to undergo physiological maturation or 'capacitation' in the female genital tract (Austin, 1952). In the mouse, the capacitation of spermatozoa seems to occur very rapidly, since sperm penetration starts as early as about $1 \mathrm{hr}$ after coitus when the females are mated after ovulation (Braden \& Austin, 1954). On the other hand, there is evidence that rabbit spermatozoa need 5 to $8 \mathrm{hr}$ for full capacitation (Austin, 1951; Chang, 1951, 1959; Noyes, Walton \& Adams, 1958). Thus, the time necessary for capacitation of spermatozoa seems to vary according to the species.

Once the time relationship between mating and sperm penetration is determined, it is not difficult to observe the process of sperm entry into the ova. Thus, Austin (1951), Austin \& Braden (1956) and Blandau \& Odor (1952) were able to observe various stages of sperm penetration into the living ova of the rat, mouse and hamster with the phase-contrast microscope. These workers, however, could not observe the actual process of sperm penetration through the zona pellucida. So far, only Pincus (1930) and Shettles (1953) have reported on the manner in which the spermatozoon penetrates the zona pellucida of the mammalian ovum.

The purpose of the present paper is to furnish further data on the time relationship between mating (or artificial insemination) and sperm penetration into the hamster ovum, and to give a description of the process of sperm penetration through the zona pellucida, which has been observed during the course of the study.

\section{Mating of animals}

\section{MATERIALS AND METHODS}

Adult virgin female golden hamsters weighing 80 to $150 \mathrm{~g}$ were used. Under controlled light conditions (light, from 06.00 hours to 18.00 hours; darkness, from 18.00 hours to 06.00 hours), most females came into oestrus between 17.00 hours and 22.00 hours every 4th day; oestrus lasted till next morning (05.00 to 09.00 hours). Ovulation (rupture of ovarian follicles) occurred most frequently about $8 \mathrm{hr}$ after the onset of oestrus (Harvey, Yanagimachi \& Chang, 1961). 
Some females were mated immediately or shortly after the onset of oestrus. Other females were not allowed to mate until the time of ovulation or several hours afterwards. Each female was permitted coitus with two fertile males for about $\frac{1}{2} \mathrm{hr}$.

\section{Artificial insemination}

Females which had been mated 4 to $5 \mathrm{hr}$ previously were killed, and the mass of spermatozoa engorging the uterine horn was squeezed out and mixed thoroughly with $4 \mathrm{ml}$ of Hanks' balanced salt solution in a watch glass. The sperm suspension thus prepared was used for insemination only if more than half of the spermatozoa displayed vigorous progressive movement. The density of spermatozoa in the suspension was about 25,000 to $80,000 \mathrm{cells} / \mathrm{mm}^{3}$. In a similar way, a suspension was prepared with spermatozoa collected from the uteri of females which were killed about $\frac{1}{2} \mathrm{hr}$ after the start of coitus. The spermatozoa in these two suspensions were designated as 4 to $5 \mathrm{hr}$ and $\frac{1}{2} \mathrm{hr}$ uterine spermatozoa, respectively. A suspension of epididymal spermatozoa was prepared by placing one cauda epididymidis of a male in $4 \mathrm{ml}$ of Hanks' solution, mincing it up with scissors, stirring thoroughly and then letting the tissue debris precipitate. The density of spermatozoa in the suspension was about 40,000 to 100,000 cells $/ \mathrm{mm}^{3}$, and these usually showed high motility.

The females to be inseminated were anaesthetized with ether about $10 \mathrm{hr}$ after the onset of oestrus (i.e. about $2 \mathrm{hr}$ after the peak of ovulation) and the uteri were exposed through a mid-ventral incision. About $0.2 \mathrm{ml}$ of the sperm suspension was injected into the lumen of each uterine horn by means of a No. 25 gauge needle attached to a tuberculin syringe.

\section{Insemination of ova in vitro}

Unfertilized ova were recovered from the Fallopian tubes between 10 and $13 \mathrm{hr}$ after the onset of oestrus. The method of insemination of the ova in vitro has been described elsewhere (Yanagimachi \& Chang, 1964). Tyrode's balanced salt solution was used to suspend spermatozoa for insemination. The density of spermatozoa in the suspension was 4000 to $8000 \mathrm{cells} / \mathrm{mm}^{3}$ in most cases.*

\section{Examination of ova}

Between 2 and $14 \mathrm{hr}$ after mating or artificial insemination, the excised Fallopian tubes were flushed with Hanks' solution (or $0.9 \% \mathrm{NaCl}$ ). If the ova were still surrounded by follicular cells, a small quantity of hyaluronidase was added to disperse them. The ova which had been inseminated in vitro were always free from the surrounding follicular cells when examined 2 to $6 \mathrm{hr}$ after insemination; the quick dispersion of follicular cells was most probably due to the action of sperm hyaluronidase.

The ova, after being briefly rinsed with Hanks' solution (or $0.9 \% \mathrm{NaCl}$ ), were mounted between a slide and a coverslip supported by four dots of vaseline-paraffin mixture, pressed moderately under the coverslip and examined

* In a previous paper (Yanagimachi \& Chang, 1964), the density of spermatozoa in the suspension was misprinted; 4000 to 8000 cells $/ \mathrm{mm}^{3}$ is correct, not 4000 to $8000 \mathrm{cells} / \mathrm{ml}$. 
with a phase-contrast microscope for evidence of sperm penetration. An ovum was recorded as being 'penetrated' when a spermatozoon was found in the perivitelline space or in the vitelline surface, or a swelling sperm head or a developing male pronucleus was discernible in the vitellus.

\section{Observation of a spermatozoon in the act of penetrating the zona pellucida}

Thirty females were mated toward the end of oestrus (05.00 to 09.00 hours) and killed 3 to $5 \mathrm{hr}$ later to remove the Fallopian tubes. After removal of the blood adhering to the tube, the tube was put at the centre of four vaseline dots on a slide and immediately covered with a drop of liquid paraffin. Both the slide and liquid paraffin were kept at 30 to $38^{\circ} \mathrm{C}$ before and during use in order to avoid temperature shock. Under a dissecting microscope the ampullary portion of the tube was dissected with two needles to let the ova, together with surrounding follicular cells and some of the tubal fluid, out of the tube. After the tube was discarded, a coverslip was put on the vaseline dots and pressed lightly so that the ova surrounded by follicular cells became clearly visible. Care was taken to avoid any compression of the ova under the coverslip. The preparation thus made was placed on the warm stage $\left(35\right.$ to $38^{\circ} \mathrm{C}$ ) of a phase-contrast microscope for further observations. The combination of an oil immersion $(\times 100)$ objective and a 10 to $15 \times$ ocular was used for examining the process of sperm penetration.

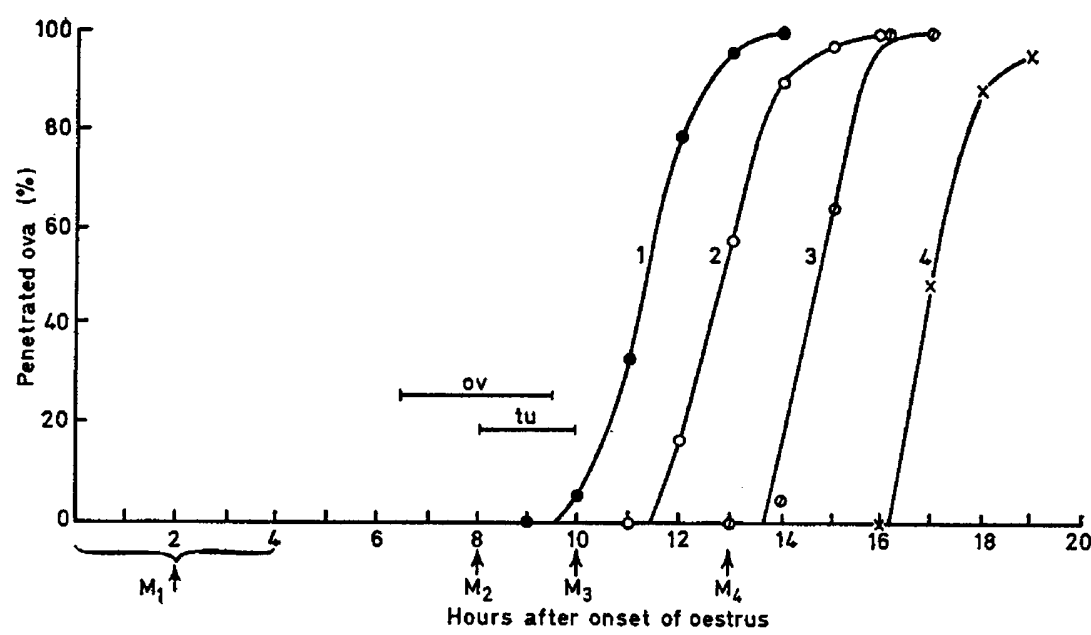

TeXT-FIG. 1. Percentage of penetrated ova in hamsters mated at various times after the onset of oestrus. Curves $1,2,3$ and 4 , mating at 1 to $4,8,10$ and $13 \mathrm{hr}$ after onset of oestrus, respectively. ov, Time of ovulation (rupture of ovarian follicles; Harvey et al., 1961); tu, time when ova pass into Fallopian tubes (Yanagimachi \& Chang, 1961).

\section{RESULTS}

TIME OF SPERM PENETRATION OF THE OVA FOLLOWING MATING

Eighty-five females were mated at various times after the onset of oestrus, and the ova, subsequently recovered from the Fallopian tubes, were examined for sperm penetration. The results obtained (Text-fig. 1) showed that when the 
females were mated shortly after the onset of oestrus $\left(M_{1}\right)$, sperm penetration of ova started about $3 \mathrm{hr}$ after the commencement of ovulation or about $1.5 \mathrm{hr}$ after the first ovum had passed into the Fallopian tube. Virtually all the ova were penetrated by spermatozoa in the next $4 \mathrm{hr}$. When the females were mated about $8 \mathrm{hr}$ after the onset of oestrus (during ovulation) $\left(\mathrm{M}_{2}\right)$, the first penetrated ovum was found $4 \mathrm{hr}$ later. A similar delay of 3 to $4 \mathrm{hr}$ between mating and the commencement of sperm penetration was also noticed when the females were mated towards the end of oestrus $\left(M_{4}\right)$.

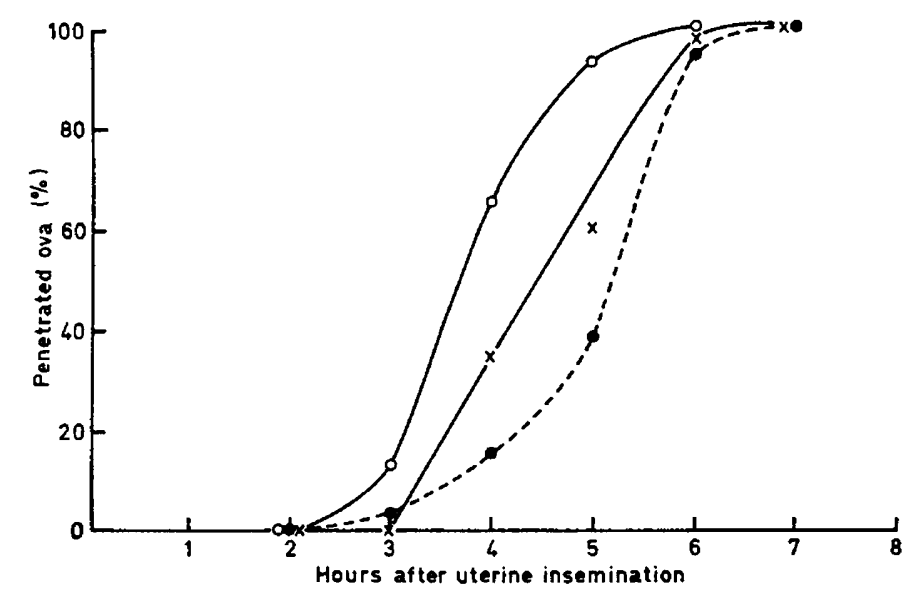

TEXT-FIG. 2. Percentage of penetrated ova in hamsters artificially inseminated at about $10 \mathrm{hr}$ after onset of oestrus with 4 to $5 \mathrm{hr}$ uterine spermatozoa $(0)$, $\frac{1}{2} \mathrm{hr}$ uterine spermatozoa $(x)$ and epididymal spermatozoa $(\bullet)$.

TIME OF SPERM PENETRATION OF THE OVA FOLLOWING ARTIFICIAL INSEMINATION

Yanagimachi \& Chang (1961) showed that virtually all the hamster ova were fertilized when epididymal spermatozoa were deposited in the uterus of females shortly after ovulation. An experiment was carried out to examine whether epididymal and uterine spermatozoa would penetrate the ova at the same rate. A total of seventy-two females was divided into three groups and inseminated with either uterine ( 4 to $5 \mathrm{hr}$ and $\frac{1}{2} \mathrm{hr}$ ) or epididymal spermatozoa about $10 \mathrm{hr}$ after the onset of oestrus, and their ova were examined for sperm penetration 2 to $7 \mathrm{hr}$ later. The results (Text-fig. 2) showed that 4 to $5 \mathrm{hr}$ uterine spermatozoa penetrated the ova significantly faster than epididymal spermatozoa; $\frac{1}{2} \mathrm{hr}$ uterine spermatozoa were intermediate with regard to the rate of penetration into the ova.

\section{TIME OF SPERM PENETRATION OF OVA in vitro}

When hamster ova were inseminated in vitro, the follicular cells surrounding the ova were quickly dispersed and several or more spermatozoa attached themselves to the surface of the zona pellucida of each ovum almost immediately after insemination (Yanagimachi, 1964). Both uterine and epididymal spermatozoa effected fertilization of 50 to $70 \%$ of ova (Yanagimachi \& Chang, 1964). In order to study when the spermatozoa start to penetrate the ova, a 
total of 638 ova were inseminated in vitro and examined for evidence of sperm penetration 1 to $7 \mathrm{hr}$ afterwards. The proportion of ova penetrated is shown in Text-fig. 3. It can be seen that neither uterine nor epididymal spermatozoa started to penetrate the ova until 2 to $3 \mathrm{hr}$ after insemination, and that the uterine spermatozoa penetrated the ova significantly faster than did the epididymal spermatozoa.

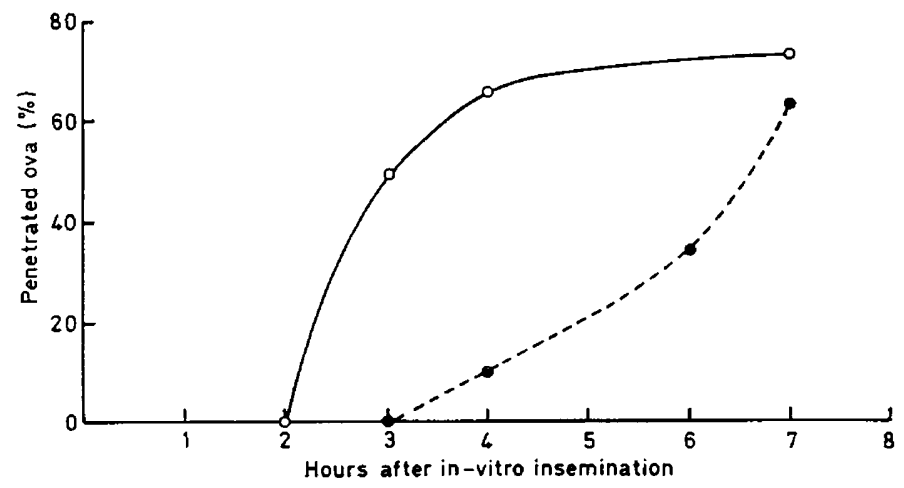

TexT-Fig. 3. Percentage of penetrated ova following in-vitro insemination at about $10 \mathrm{hr}$ after onset of oestrus with 4 to $5 \mathrm{hr}$ uterine spermatozoa $(0)$ and epididymal spermatozoa (O).

\section{MANNER OF SPERM PENETRATION THROUGH ZONA PELLUCIDA}

More than 300 ova were recovered from the Fallopian tubes at about the time of sperm penetration, and searched for spermatozoa in the act of penetrating through the zona pellucida. On several occasions a spermatozoon was found inserting its head into the thickness of the zona pellucida (Pl. 1, Figs. 4 to 7). Such a spermatozoon would be beating its flagellum very vigorously when first examined, but this movement gradually diminished and the spermatozoon never passed through the zona pellucida during the period of observation. In many ova examined, a spermatozoon had already passed into the perivitelline space or into the vitellus, leaving a slit in the zona pellucida (Pl. 1, Figs. 8 and 9 ). The whole process of sperm penetration through the zona pellucida was observed on one occasion during this study.

The ovum into which a spermatozoon penetrated through the zona pellucida during the period of observation was one of seven collected from a Fallopian tube of a female mated between 07.00 hours and 07.30 hours and killed at

\section{EXPLANATION OF PLATE 1}

FIGs. 1 to 3. Comparison of sperm heads with intact (1), lifted (2) and no outer acrosome membrane (3). All of these spermatozoa were highly motile before photography. Fig. 1, an epididymal spermatozoon; Figs. 2 and 3 , spermatozoa attaching to the surface of the zona pellucida of ova recovered from the Fallopian tubes $4 \mathrm{hr}$ after coitus. $\times 1500$.

Figs. 4 to 7. Sperm heads in thickness of zona pellucida. All of these spermatozoa were motile before photography. $\times 1500$

FrG. 8. Sperm flagellum lying partly in and partly outside the zona pellucida, showing the slanting passage of a spermatozoon through the zona pellucida. $\times 1500$.

Fig. 9. A slit in the zona pellucida made by a penetrating spermatozoon. $\times 1500$. 
PLATE 1

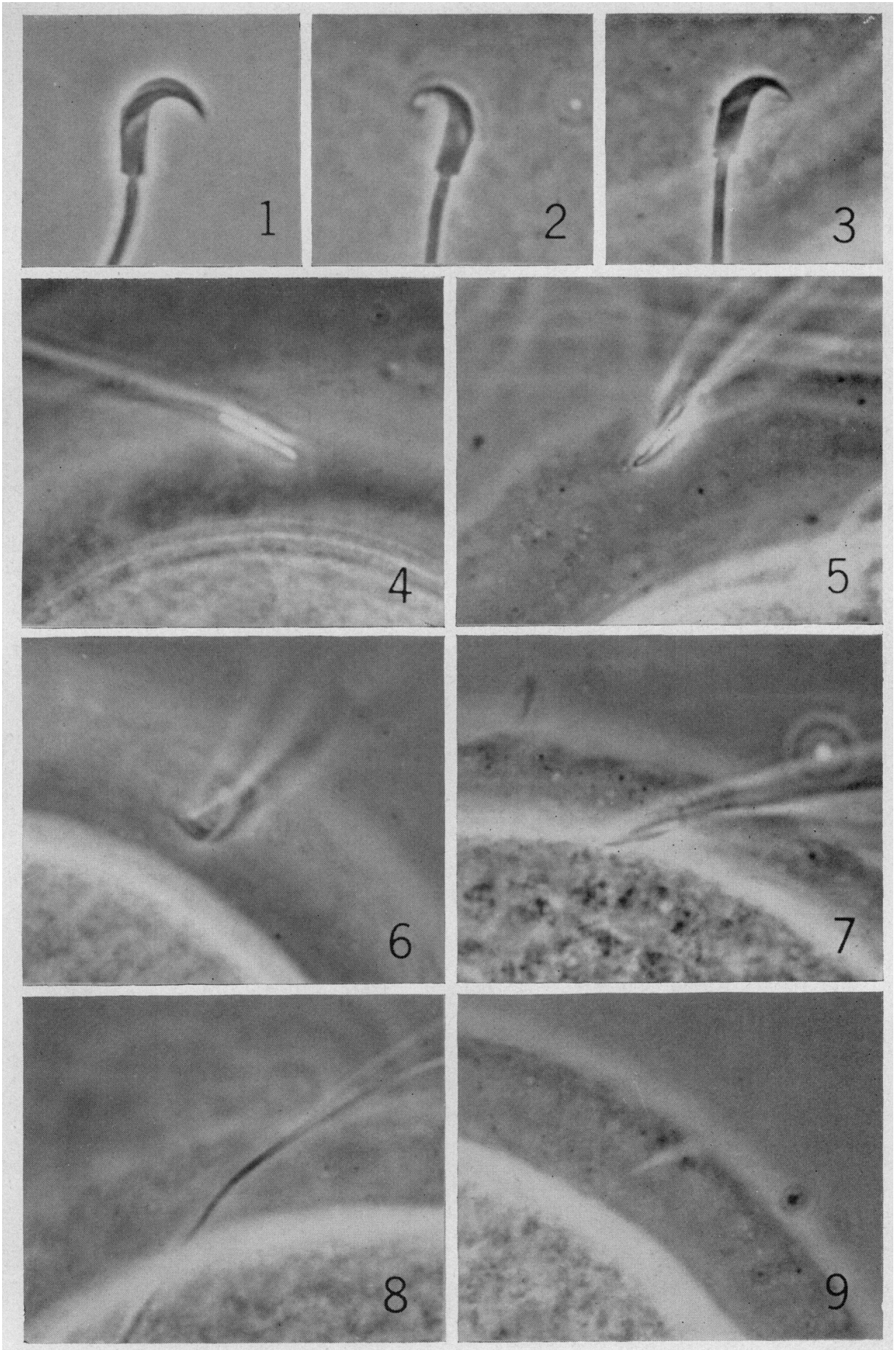

(Facing p. 364) 
10.20 hours. All seven ova, when recovered from the tube, were free from follicular cells and were naked. About twenty spermatozoa were seen actively swimming among the dispersed follicular cells. Five of these seven ova had been penetrated by spermatozoa, and the undulating motion of the sperm flagella lying free in the perivitelline space was observed. When examined at 10.30 hours, an active spermatozoon was found attached to the surface of the zona pellucida of one of the two unpenetrated ova. The flagellum of this spermatozoon

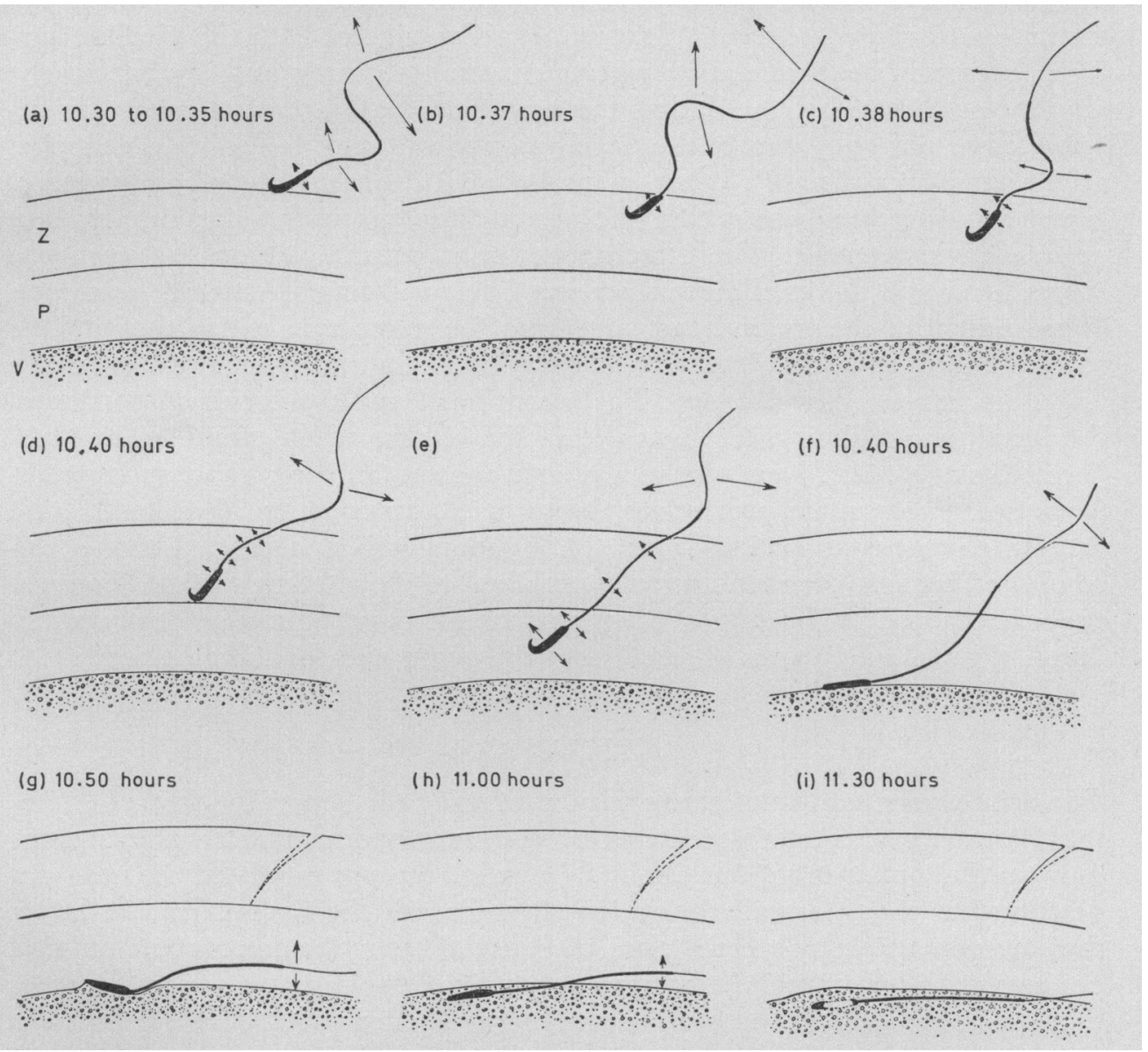

TexT-RIG. 4. Semi-diagrammatic representation of successive stages in penetration of a hamster ovum by a spermatozoon. Arrows indicate amplitude of movement of sperm head and flagellum. P, perivitelline space; V, vitellus; Z, zona pellucida. Explanation in text.

was beating vigorously. The acrosome (at least, the outer acrosome membrane, according to Colwin \& Colwin's terminology, 1965) was not visible in this spermatozoon (cf. Pl. 1, Figs. 1 to 3). At 10.35 hours the head of the spermatozoon was still outside the zona pellucida (Text-fig. 4a). When examined at 10.37 hours the sperm head was found embedded in the thickness of the zona pellucida (Text-fig. 4b). At 10.38 hours the head was in the middle of the zona pellucida (Text-fig. 4c). The vigorous motion of the flagellum forced the head 
forward a little at a time, but steadily. The direction of the passage was not vertical, but at an angle to the surface of the zona pellucida. Small particles in the zona pellucida near the head and the proximal portion of the flagellum (middle piece) moved back and forth as the head and flagellum moved, suggesting that the pathway of the sperm head was less viscous than the rest of the zona pellucida. The sperm head reached the inner surface of the zona pellucida at 10.40 hours (Text-fig. $4 \mathrm{~d}$ ). Immediately, the head became free in the perivitelline space and the spermatozoon dashed forward to reach the vitelline surface in 1 to $2 \mathrm{sec}$ (Text-fig. 4e). On contact with the vitelline surface, the sperm head ceased its vigorous motion abruptly and lay flat on the vitelline surface. The undulating motion of the flagellum was markedly reduced. The posterior part of the flagellum was still outside the zona pellucida at this time (Text-fig. 4f). When examined at 10.50 hours, the whole length of the sperm flagellum was within the perivitelline space, showing intermittent undulating movement. The attachment (or membrane fusion) between the sperm head and the vitelline surface was obvious from the marked restriction of movement of the sperm head, and from the manner in which the vitelline surface adjacent to the head was slightly lifted up and pushed down as the flagellum moved (Text-fig. 4g). The sperm head and the proximal portion of the flagellum (middle piece) was within the vitellus when examined at 11.00 hours (Text-fig. 4h). Next, the sperm head showed an early phase in its transformation into a male pronucleus, losing its sharp contour (Text-fig. 4i). No further change was noticed until 11.30 hours, when observation was discontinued because of deterioration (wrinkling) of the vitelline surface. This was probably caused by shortage of oxygen in the surrounding medium or accumulation of metabolic wastes diffused from the ovum and the follicular cells.

\section{DISGUSSION}

The data presented in this study have confirmed the report by Strauss (1956) that hamster ova are not penetrated by spermatozoa immediately after passing into the Fallopian tube, but about $2 \mathrm{hr}$ later. Strauss suggested that the ova need further physiological maturation after entering the Fallopian tubes before they are penetrable by spermatozoa, although this may be due to some physical or chemical alteration of the gelatinous matrix of the cumulus oophorus rather than to maturation of the ova themselves, as Braden (1962) has suggested in the mouse.

The existence of a 4-hr interval between delayed mating (mating after ovulation) and the commencement of sperm penetration into hamster ova was also reported by Strauss (1956), and confirmed in the present study. It seems more reasonable to interpret this time interval as suggesting the necessity of capacitation of spermatozoa (Austin, 1952; Austin \& Walton, 1960) rather than sperm transport to the site of fertilization (Strauss, 1956), since the hamster spermatozoa may arrive at the site of fertilization (ampullary portion of the Fallopian tube) within $1 \mathrm{hr}$ after mating (Yanagimachi \& Chang, 1963).

The capacitation of hamster spermatozoa was ascribed by Austin \& Bishop (1958) to changes in the acrosome. They observed that spermatozoa recovered 
from the Fallopian tube or from the cumulus oophorus had modified acrosomes, or even lacked this structure, and those found in the zona pellucida or in the perivitelline space of the ovum were invariably devoid of this structure. After observing the same phenomenon in guinea-pig and Libyan jird, Austin \& Bishop (1958) expressed an opinion that the modification and eventual detachment of the acrosome is directly associated with the capacitation of spermatozoa. This theory, however, does not hold for the rabbit, because uterine spermatozoa which are believed to be capacitated have an intact acrosome (Chang \& Slechta, cited from Chang, 1959; Bedford, 1964); noticeable structural changes in the acrosome occur only after the spermatozoon has started to enter the zona pellucida (Hadek, 1963; Austin, 1963a). Thus, the structural modification of the acrosome cannot be taken to reflect the entire process of capacitation. It seems to be more feasible to assume that capacitation occurs in two stages; in the first there is some kind of physiological change, and this makes possible the second which is represented by the acrosome modification (Austin, $1963 \mathrm{~b}, 1964)$. The first stage of capacitation appears to occur as the spermatozoa ascend through the uterus and Fallopian tube. In the rabbit, the second stage of capacitation does not start until the sperm head begins to enter the zona pellucida (Hadek, 1963; Austin, 1963a). On the other hand, in the hamster, and probably in the guinea-pig and Libyan jird, this stage may be initiated while the spermatozoa are traversing the Fallopian tube and is completed before the spermatozoa make contact with the surface of the zona pellucida (Austin \& Bishop, 1958). Thus, the place where the capacitation of spermatozoa is completed seems to differ according to the species.

Noyes (1953), carrying out artificial insemination of rats to compare the fertilizing capacities of uterine ( $7 \mathrm{hr}$ incubated) and epididymal spermatozoa, demonstrated that the uterine spermatozoa penetrated the ova about $2 \mathrm{hr}$ earlier than epididymal spermatozoa. Although essentially the same result was obtained in the hamster, it is unlikely that uterine spermatozoa have been fully capacitated at the time of recovery. This is because they apparently have an intact acrosome (Yanagimachi \& Chang, 1964), and have to spend at least 2 hours more before they accomplish the modification of their acrosome and start to penetrate the zona pellucida. These spermatozoa can only have accomplished a partial capacitation. For full capacitation, sojourn in the Fallopian tube and contact with tubal fluid or substances produced by the ova and follicular cells appears to be necessary.

It is surprising that only two workers, namely Pincus (1930) and Shettles (1953), have observed the process of sperm penetration through the zona pellucida of the mammalian ovum. According to Pincus (1930), the rabbit spermatozoon entered the zona pellucida at right angles to the axis of the ovum, proceeded slowly through the zona pellucida towards the ovum proper and finally entered the vitellus, the tail being left in the zona pellucida. Shettles (1953) described in some detail how a human spermatozoon penetrated the zona pellucida of a follicular ovum which had been inseminated in vitro. He stated that the spermatozoon attached to the zona pellucida at right angles to its surface and passed into the zona pellucida, rotating on its longitudinal axis. The time required for the spermatozoon to traverse the zona pellucida was 
$18 \mathrm{~min}$; the spermatozoon moved about in the perivitelline space for about $6 \mathrm{hr}$.

The fact that few workers have observed spermatozoa penetrating the zona pellucida has led previous workers to suggest that sperm penetration through the zona pellucida must be a very rapid process, probably taking no more than a few minutes (e.g. Austin, 1951). Although the whole process of sperm penetration through the zona pellucida was observed on only one occasion in the present study, and both ovum and spermatozoon were under subnormal physiological conditions (i.e. between slide and coverslip and under continuous illumination), the description of the event provides some evidence as to how a spermatozoon passes through the zona pellucida of the mammalian ovum. Particular mention is made of the following points:

(1) In the hamster spermatozoon which was about to enter the zona pellucida, the acrosome (at least, the outer acrosome membrane and overlying plasma membrane) was absent. This implies that the contents of the acrosome, most probably hyaluronidase, have been released and that the inner acrosome membrane and underlying perforatorium are exposed. Piko (1964) suggests that the tip of the acrosome of the rat spermatozoon opens up on contact of the spermatozoon with the cumulus oophorus. In the rabbit, according to Hadek (1963), the acrosome membrane does not start to modify or disintegrate until the sperm head passes into the zona pellucida. Despite difference in the place of commencement of acrosome modification, it is common to all these species that the inner acrosome membrane makes a direct contact with the material of the zona pellucida when the spermatozoon traverses the zona pellucida (Austin, 1963a; Hadek, 1963; Piko \& Tyler, 1964).

(2) The hamster spermatozoon passed through the zona pellucida in 3 to 4 min. Under natural circumstances the spermatozoon must traverse the zona pellucida even faster. It is obvious that the hamster spermatozoon traverses the zona pellucida much faster than does the human spermatozoon (4 versus $18 \mathrm{~min})$.

(3) The direction of passage of the spermatozoon was not vertical, but at an angle to the surface of the zona pellucida. A slanting and curved slit in the zona pellucida, believed to be left in the pathway of the fertilizing spermatozoon, has been photographed by Austin \& Bishop (1958) in the guinea-pig and Libyan jird, by Dickmann (1964) in the rabbit, by Dickmann \& Dziuk (1964) in the pig and by Dziuk \& Dickmann (1965) in the sheep. The slanting passage of the spermatozoon through the zona pellucida seems to be common to various mammalian species.

Dickmann (1964) and Dickmann \& Dziuk (1964) photographed a filamentlike structure extending from the apex of supplementary spermatozoa which were embedded in the zona pellucida of rabbit and pig ova. These workers have conjectured that such a filament is ejected from the fertilizing spermatozoon upon contact with the zona pellucida, and that this filament guides the spermatozoon through the zona pellucida. In the fertilizing spermatozoon of the hamster which was in the act of penetrating the zona pellucida, the corresponding filament-like structure was not observed. On the other hand, a somewhat similar filament-like structure or image was seen, on a few occasions, 
extending from the apex of hamster spermatozoa which failed to pass through the zona pellucida (Yanagimachi, 1964). Further studies are needed to learn the real nature of this filament.

(4) A slit was made in the zona pellucida as a spermatozoon passed through it. The perforatorium and overlying inner acrosome membrane which are in direct contact with the material of the zona pellucida appear to alter the physical or chemical properties of the zona pellucida. The agent which is responsible for this alteration (hypothetical zona lysin) seems to be located in, or closely associated with, the perforatorium. Although the same opinion has already been expressed by Austin \& Bishop (1958), Piko (1964) suggests that the lysin is located in the acrosome, not in the perforatorium. Recently, Srivastava, Adams \& Hartree (1965) reported that a preparation of lipoglycoprotein extracted from the isolated acrosomes of ram, bull or rabbit spermatozoa dispersed the corona cells surrounding rabbit ova and sometimes even dissolved the zona pellucida. The zona lysin may therefore be a substance related to lipoglycoprotein.

(5) The fertilizing spermatozoon sank into the vitellus without any lively motion. The entry or incorporation of the spermatozoon into the vitellus appears to be the function of the vitelline cortex rather than that of the spermatozoon as suggested by Austin \& Braden (1956). Although the spermatozoon may display vigorous motion even after its entry into the vitellus (Blandau \& Odor, 1952), sperm motility itself is not a sine qua non for successful incorporation of the spermatozoon into the vitellus.

\section{ACKNOWLEDGMENTS}

This study was supported by a grant (GM-10529) from N.I.H., U.S. Public Health Service and a grant from the Lalor Foundation.

The author wishes to express his sincere gratitude to Dr M. C. Chang for his invaluable advice and encouragement. The author is also indebted to Dr M. J. K. Harper for his assistance in reading the manuscript.

\section{REFERENCES}

Austin, C. R. (1948) Function of hyaluronidase in fertilization. Nature, Lond. 162, 63.

Austis, C. R. (1951) Observations on the penetration of the sperm into the mammalian egg. Aust. $\mathcal{F}$. Sci. Res. B, 4, 581.

Austrs, C. R. (1952) The capacitation of the mammalian sperm. Nature, Lond. 170, 326.

Austis, C. R. (1956) Ovulation, fertilization and early cleavages in the hamster (Mesocricetus auratus). Fl R. microsc. Soc. 75, 141.

Austin, C. R. (1963a) Acrosome loss from the rabbit spermatozoon in relation to entry into the egg. 7. Reprod. Fert. 6, 313.

Austis, C. R. (1963b) Fertilization and transport of the ovum. Mechanisms Concerned with Conception, p. 285. Ed. C. G. Hartman. Pergamon Press, London.

Austin, C. R. (1964) Behavior of spermatozoa in the female genital tract and in fertilization. Proc. Vth int. Congr. Anim. Reprod. Trento, Italy, 3, 7.

Austin, C. R. \& Bishop, M. W. H. (1958) Role of the rodent acrosome and perforatorium in fertilization. Proc. R. Soc. B, 148, 241.

Austin, C. R. \& Braden, A. W. H. (1954) Time relations and their significance in the ovulation and penetration of eggs in rats and rabbits. Aust. F. biol. Sci. 7, 179.

Austin, C. R. \& BRADEN, A. W. H. (1956) Early reactions of the rodent egg to spermatozoon penetration. 7. exp. Biol. 33, 358. 
Austin, C. R. \& Walton, A. (1960) Fertilization. Marshall's Physiology of Reproduction, 3rd edn, Vol. I (2), p. 310. Ed. A. S. Parkes. Longmans Green, London.

BEDFord, J. M. (1964) Fine structure of the sperm head in ejaculate and uterine spermatozoa of the rabbit. F. Reprod. Fert. 7, 221.

Blandau, R. J. \& Money, W. L. (1944) Observations on the rate of transport of spermatozoa in the female genital tract of the rat. Anat. Rec. 90, 255.

Blandau, R. J. \& Odor, D. L. (1952) Observations on sperm penetration into the ooplasm and changes in the cytoplasmic components of the fertilizing spermatozoon in rat ova. Fert. Steril. 3,13 .

Braden, A. W. H. (1962) Spermatozoon penetration and fertilization in the mouse. Symp. genet. Biol. Italica, Pavia, Italy, 9, 1.

Braden, A. W. H. \& Austin, C. R. (1954) Fertilization of the mouse egg and the effect of delayed coitus and of hot-shock treatment. Aust. F. biol. Sci. 7, 552.

Chang, M. C. (1951) Fertilizing capacity of spermatozoa deposited in the Fallopian tubes. Nature, Lond. 168, 697.

Chang, M. C. (1959) Fertilizing capacity of spermatozoa. Recent Progress in Endocrinology of Reproduction, p. 131. Ed. C. W. Lloyd. Academic Press, New York.

Chang, M. C. \& Bedford, J. M. (1962) Fertilizability of rabbit ova after removal of the corona radiata. Fert. Steril. 13, 421.

Colwin, A. L. \& Colwrs, L. H. (1965) Suggested similarity between early events of fertilization in certain mammals and invertebrates. Anat. Rec. 151, 447.

Drckmann, Z. (1964) The passage of spermatozoa through and into the zona pellucida of the rabbit egg. F. exp. Biol. 41, 177.

Dickmann, Z. \& Dzruk, P. J. (1964) Sperm penetration of the zona pellucida of the pig egg. F. exp. Biol. 41, 603.

Dziuk, P. J. \& Dickmann, Z. (1965) Sperm penetration through the zona pellucida of the sheep egg. 7. exp. Zool. 158, 237.

HADEK, R. (1963) Submicroscopic changes in the penetrating spermatozoon of the rabbit. F. Ultrastruct. Res. 8, 161 .

Harvey, E. B., Yanagmachi, R. \& Chang, M. C. (1961) Onset of estrus and ovulation in the golden hamster. F. exp. Zool. 146, 231.

Lewis, W. H. \& Wright, E. S. (1935) On the early development of the mouse egg. Carnegie Inst. Wash. Contrib. Embryol. 25, 113.

Moricard, R. \& Bossu, J. (1949) Numération des spermatozoides au voisinage de l'ovocyte de lapine. Bull. Ass. Gynéc. Obstét. Lang. France, $1,30$.

Noyes, R. W. (1953) Fertilizing capacity of spermatozoa. West. J. Surg. Obst. Gynec. 61, 342.

Noyes, R. W., Walton, A. \& AdAMs, C. E. (1958) Capacitation of rabbit spermatozoa. F. Endocr. 17, 374.

Opor, D. L. \& BLANDAU, R. J. (1951) Observations on fertilization and the first segmentation division in the rat ova. Am. F. Anat. 89, 29.

PIKo, L. (1964) Mechanism of sperm penetration in the rat and the Chinese hamster based on fine structural studies. Proc. Vth int. Congr. Anim. Reprod., Trento, Italy, 7, 301.

Piko, L. \& TYLeR, A. (1964) Fine structural studies of sperm penetration in the rat. Proc. Vth int. Congr. Anim. Reprod., Trento, Italy, 2, 372.

Pincus, G. (1930) Observations on the living eggs of the rabbit. Proc. R. Soc. B, 107, 132.

SHETTLEs, L. B. (1953) Observations on human follicular and tubal ova. Am. F. Obstet. Gynec. 66, 235.

Srivastava, P. N., Adams, C. E. \& HarTree, E. F. (1965) Enzymatic action of lipoglycoprotein preparations from sperm-acrosomes on rabbit ova. Nature, Lond. 205, 498.

Strauss, F. (1956) The time and place of fertilization of the golden hamster egg. F. Embryol. exp. Morph. $4,42$.

Yanagimachr, R. (1964) Sperm penetration into hamster egg in vitro. Proc. Vth int. Congr. Anim. Reprod., Trento, Italy, 3, 321.

Yanagimachi, R. \& Chanc, M. C. (1961) Fertilizable life of golden hamster ova and their morphological changes at the time of losing fertilizability. 7. exp. Zool. 148, 185.

Yanagimachi, R. \& Chang, M. C. (1963) Sperm ascent through the oviduct of the hamster and rabbit in relation to the time of ovulation. 7 . Reprod. Fert. $6,413$.

YanagmachI, R. \& Chang, M. C. (1964) In vitro fertilization of golden hamster ova. 7. exp. Zool. 156,361 . 